Article

\title{
Sustainable Entrepreneurship Orientation: A Reflection on Status-Quo Research on Factors Facilitating Responsible Managerial Practices
}

\author{
Sascha Kraus ${ }^{1, *}$, Janina Burtscher ${ }^{1}$, Christine Vallaster ${ }^{2}$ and Martin Angerer ${ }^{1}$ \\ 1 University of Liechtenstein, Fuerst-Franz-Josef-Strasse, 9490 Vaduz, Liechtenstein; \\ janina.burtscher@uni.li (J.B.); martin.angerer@uni.li (M.A.) \\ 2 Salzburg University of Applied Sciences, Urstein Süd 1, 5412 Puch/Salzburg, Austria; \\ christine.vallaster@fh-salzburg.ac.at \\ * Correspondence: sascha.kraus@uni.li; Tel.: +423-265-1282
}

Received: 30 December 2017; Accepted: 4 February 2018; Published: 8 February 2018

\begin{abstract}
With the global financial system having undergone vast changes since the financial crisis of 2007, scientific research concerning the investor's point of view on sustainable investments has drastically increased. However, there remains a lack of research focused on the entrepreneur's angle regarding sustainable oriented investments. The aim of this paper is to contribute to the understanding of sustainable financial markets by bringing together entrepreneurial and financial research. This paper provides a structured literature review, based on which the authors identify three relevant levels that they believe have an effect on the successful implementation of managerial sustainable practices; these are the individual, the firm, and the contextual levels. The results show that on the individual level sustainable entrepreneurs tend to derive their will to act more sustainably from their personal values or traits. On the organizational level, though, it can be concluded that an small and medium sized enterprise's internal culture and the reconfiguration of resources are critical determinants for adopting a sustainable entrepreneurial orientation. Finally, on the contextual level, researchers have focused on a better understanding of how entrepreneurs can help society and the environment through sustainable entrepreneurship, and how they can act as role models or change agents in light of the fact that the choice of investing or financing based on sustainability is still in its infancy. By providing an overview on facilitating factors for responsible managerial practices on the entrepreneur's side, this research contributes to a better understanding for both theory and practice on how sustainable practices can be implemented and facilitated.
\end{abstract}

Keywords: sustainable entrepreneurship orientation; SEO; managerial sustainable practices; MSP; sustainable entrepreneurship; sustainable development

\section{Introduction}

The global financial system has undergone a huge transformation process since the financial crisis of 2007 and the subsequent crises. One main driver of the turbulence was the dominating objective of securing fast profits with high leverage, neglecting sustainability, and other social aspects [1]. The financial (investor-side-based) academic literature has immediately responded, and already offers a huge number of studies on the development and performance of companies that do business in a sustainable way. Friede et al. contribute a literature review of over 2000 studies, just on the topic of financial performance of Environmental, Sustainable, and Green (ESG) investments [2]. Others look at more specific cases, e.g., [3], and use a database on eco-efficiency scores to find that companies that have good scores also have better financial performance. These studies also show that financial performance is time-lagged with better scores. However, the financial system consists not only of 
investors, but also of entrepreneurs, who choose how to run their companies. While the investor's point of view on sustainable investments and a sustainable system is already heavily researched, there is a lack of research on the side of entrepreneurs. In this paper, we develop this side, in order to contribute to the understanding of sustainable financial markets by bringing together entrepreneurial and financial research.

Although the importance of sustainable entrepreneurship has increased in academia, as well as in the global societal discourse, the concept itself is still developing [4-6]. While common entrepreneurship theories are based on discovering and exploiting economic opportunities through entrepreneurial orientation (EO) [7], sustainable entrepreneurship deals with the transformation of society towards a more environmental, social, and economic equilibrium through sustainable entrepreneurial orientation (SEO) [8]. Research on this field has evolved, and includes the "green entrepreneur", the "social entrepreneur", and the "sustainable entrepreneur" [9], following the same ESG structure as the financial literature.

First introduced by Berle, green entrepreneurship is widely concerned with environmental challenges [10]. Green entrepreneurs build their businesses with environmental values as their foundation. But taking these into account, they also seek competitive advantages [11]. The US outdoor clothing company Patagonia (patagonia.com) is a green enterprise, and its business model blends entrepreneurial goals with a successful economic return (profit, market share, etc.), while minimizing its negative impact on the environment wherever possible. Patagonia's mission statement is "Build the best product. Cause no unnecessary harm. Use business to inspire and implement solutions to the environmental crisis." Ecological entrepreneurship can here be defined as a process where opportunities are identified, analysed, and taken on with the aim of minimizing a firms' exploitation of the natural environment, generating benefits for future societal and economic needs in the process.

Social entrepreneurs assign the utmost priority to the creation of social value, with economic value creation only being a necessary condition for financial viability [12,13]. Magda's hotel in Vienna, Austria (magdas-hotel.at) is an example of this kind of "hybrid organisation", in the way that it combines features from both the non-profit and for-profit sectors [14]. The hotel is run completely by refugees (who are legally permitted to work in Austria). A profit orientation characterises their work approach. The identity of Magda's hotel is thus formed by both social ambitions and utilitarian economics [15].

Researchers like Isaak [16] or Schaltegger and Wagner [17] have linked green entrepreneurship and social entrepreneurship to sustainable entrepreneurship, as all three categories share the common goal of positive environmental impacts. Sustainable entrepreneurship in existing firms, especially small and medium sized enterprises (SMEs), is led by an entrepreneur who carries out managerial sustainable practices (MSP) through innovation and creating value [6]. SEO is crucial for the implementation of sustainable entrepreneurship within an organization, making corporate social responsibility a strategic issue [18]. While strong research has evolved around strategic corporate social responsibility e.g., [19-23], a lack of structured review remains to understand both the investors' and the entrepreneurs' side, in order to establish a sustainable financial system. Particularly, there is a lack of consensus when it comes to identifying entrepreneurial sustainability practices [24].

In this paper, we aim to close this gap, by providing a structured literature review drawing on the structure that Spence et al. [25] introduced. Here the authors identify three relevant levels, which they believe have an effect on the successful implementation of managerial sustainable practices: the individual, the firm, and the contextual levels.

The remaining part of this paper is structured as follows. The first part of the literature review sets the stage for and defines the influence of corporate social responsibility regarding entrepreneurship orientation (EO), followed by a discussion that shifts the perspective from EO to SEO. The second part introduces the methodology used for this structured review process. Finally, the reviewed research highlights foundational factors thought to influence sustainable entrepreneurial managerial practices. We conclude with a look at further paths for future research. 


\section{Setting the Stage}

Sustainable entrepreneurship, in this paper, is defined as the need to integrate environmental, social, sustainable, and economic activities. The environmental aspect typically attempts to reduce the exploitation of valuable resources and the environment, decrease the creation and use of harmful substances, and curb environmental pollution and waste production [26-28]. Sustainability in the social realm can involve promoting social integration; nurturing societies that are characterized by safety, stability, and justice; advancing and protecting human rights, diversity, and equality; and securing livelihoods [29]. A possible definition here (that is balanced with the more long-term view of sustainable development) is provided by Choi and Gray, who conceive of sustainable entrepreneurs as "individuals who are creating and building profitable companies that also pursue environmental or social causes" [30].

\subsection{The Influence of Corporate Social Responsibility on Entrepreneurship Orientation}

With the above understanding in mind, sustainable entrepreneurship is strongly linked to the recent discussion revolving around corporate social responsibility (CSR). Not only within the academic world is CSR gaining a significant amount of relevance-it is also becoming an increasingly pressing item for the agendas of corporations as well. While the traditional focus of corporations should be to conduct their activities in a profitable manner, studies regarding CSR argue that a socially responsible corporation should, besides make a profit, strive to obey all applicable laws, behave in an ethical and responsible way, and be a "good corporate citizen" [31-33].

A growing amount of research has delivered numerous definitions of CSR, to address what exactly is the meaning of being socially and ecologically responsible for companies. The most widely adopted definition of CSR has been the result of the work by Carroll [34], who designed a model consisting of four major pillars of responsibilities, including economic, legal, ethical, and philanthropic responsibilities. As the traditional main objective of businesses is to conduct them in a profitable manner, a major topic within the literature is whether companies should be concerned with other responsibilities besides their own, often sole responsibility of simply achieving a profit [35].

Multiple studies in business literature have recently focused on corporate social responsibility and the entrepreneurial orientation of businesses. As studies have shown, CSR is an important and even central priority for companies, as is their management within their daily business activities, due to CSR's ability to create shared value [36]; CSR is also a key factor in increasing greater social cohesion. This in turn leads to a higher degree of sustainable economic growth, encompassing economic, social, and environmental goals [37].

Entrepreneurial orientation of businesses is regarded as a predictor of the success of corporations [38]. After all, the entrepreneurial orientation of enterprises has a significant influence on business performance, and creates value [39-42]. Looking at the financial performance of stock companies classified as ESG investments, Auer et al. [43] find that overall those companies' performance is comparable to the broad market, and only worse in some sub-regions and sub-ESG classes. Furthermore, an entrepreneurial orientation has an even more rigorous effect on a more general level, because it is deemed capable of improving the economy on a macroeconomic scale through the creation of wealth. It can therefore be of essential help on the way to a more sustainable financial system as a whole. It also encourages and facilitates the degree of competition within today's global employment environment [44], making it one of the top priorities of many governments [45].

The action a firm takes in response to environmental pressure can be shaped by the entrepreneurial strategies it adopts, enabling a firm to improve its sustainability activities [46]. Based on the traditional literature on entrepreneurship, the sole focus has been this topic's relationship to economic development, merely observing the economic impact of enterprises, e.g., Schumpeter [7]; the link between entrepreneurship and sustainable development has gained academic interest only very recently [6,47]. To effectively be able to compete within a market, companies must develop new and innovative ways to secure their long-term existence [48]. Therefore, fostering the positive factors 
and actively curbing the negative factors within the market makes analyses of what affects business performance necessary. Not until the emergence of the stakeholder theory, formally introduced by Freeman [49], had CSR attracted much academic attention, even though its origins date back to the beginning of the 20th century [50]. Now a priority for companies and managers in today's world [36], CSR has been strategically integrated into the core of many firms' activities [18], thanks to its ability to create shared value for businesses and society alike [37].

\subsection{Moving from Entrepreneurial Orientation to Sustainable Entrepreneurial Orientation}

More researchers have recently devoted their attention to sustainable entrepreneurial orientation (SEO), an idea formed out of the concepts of entrepreneurial orientation (EO) $[39,41]$ as well as sustainability orientation (SO) [51].

First introduced by Miller [41], EO has become a much-researched topic in business science [52]. Today it is one of the most prominent research topics within entrepreneurship research [53]. While this growing research led to an establishment of comprehensive knowledge [44,54-56], it also resulted in multiple reformulations of its original conception. Miller's original notion of EO is based on the three dimensions of proactiveness, innovativeness, and risk-taking [41]. The innovativeness of a firm can be measured by observing the actions taken towards engaging and backing new ideas, advocating creative measures, and encouraging experiment and testing processes. Actions like these are linked to product service and process innovation [57]. A popular indicator of the proactiveness of a company is its willingness to anticipate and react to changes in the future, a behaviour often resulting in proactive enterprises being the "first movers" and forerunners on the market $[57,58]$, while reactive companies respond and follow.

Acting entrepreneurially requires enduring a certain amount of risk and uncertainty, as well as a high probability of loss. This is often used synonymously with a propensity towards risk-taking [59]. However, this readiness to invest in opportunities that go along with this uncertainty about the prospect of succeeding often does not include blindly investing in high-risk and uncontrollable ventures, but rather taking calculated risks after an extensive examination of possible outcomes [60]. Miller and Friesen [61] clearly understand EO as a decision-making process, affecting not only the enterprise's willingness to innovate, but to outshine the competition with regard to proactiveness and taking risks. Enterprises implementing EO as their strategic orientation are able to discover, evaluate and exploit new opportunities to create new products, services, and processes [54,62,63]. Gasser et al. [64] provide evidence from financial stock markets that stock returns of ESG-rated companies are a slightly lower, but not riskier than others, when considering standard deviation as a measure. Running a sustainable and competitive business is therefore also not expected to be riskier by the financial markets.

Just like EO, SEO is a strategic orientation formed in the context of a competitive culture [65]. While EO is a popular research topic, SEO is a rather novel research issue, which has only recently grabbed the attention of researchers such as Bos-Brouwers [51] and Kuckertz and Wagner [66]. Although in most cases SEO is conceptualized on the individual level [67], in the context of forming a definition for SEO, Bos-Browers defined it as a unidimensional system, which displays itself in three different schemes that build upon the firms' perception of sustainability: as a cost, an obligation, or an opportunity [51]. Moreover, SEO also consists of two underlying factors enabling the implementation and integration of sustainability into the enterprise: consciousness and motivation [51,68]. By integrating sustainability into their business strategy, enterprises enable themselves to respond to the uncertainty of their environment, and therefore adapt their strategic orientation correspondingly [69].

Current research shows that in order to be able to respond to market changes, rather than focusing on one strategic orientation, companies have to build their strategy based on multiple ones $[63,65]$. These numerous strategic orientations then build an overall strategic orientation of the company [70]. One of these overall strategic orientations emerging out of two different strategic orientations includes SEO. Criado-Gomis et al. suggest that the difficulty of implementing measures 
regarding sustainable development can be reduced by incorporating SEO as a strategic resource [71], which enables companies to implement triple-bottom-line objectives into their corporate culture. The combination of the decision-making and behavioural aspects of EO, with innovativeness, proactiveness, and risk-taking [41], on the one hand, and SO with consciousness and awareness of sustainable development on the other [51], builds a unique strategic opportunity for the sustainable enterprise to be on the market's cutting edge, to grow, and to remain in business for the long haul [71].

Although research has been on the rise, there is a lack of a structured research review identifying sustainable entrepreneurial managerial practices on an individual, organizational, and contextual/market level. We contribute to the literature by closing this gap, and outline in the following paragraphs the methodology for our literature review.

\section{Literature Review Approach}

The procedure of this literature review was based on Tranfield, Denyar, and Smart [72]. This review method was chosen because of its tenacity. It enables the reviewers to minimize bias by researching and reviewing a distinct topic, with autonomous reviewers debating the overall method as well as the incorporation and elimination of articles [72]. Furthermore, by outlining the steps taken, the method provides transparency, as the steps could potentially be reproduced by other researchers [72]. The steps that were taken in this research are described in the following paragraphs and illustrated in Figure 1.

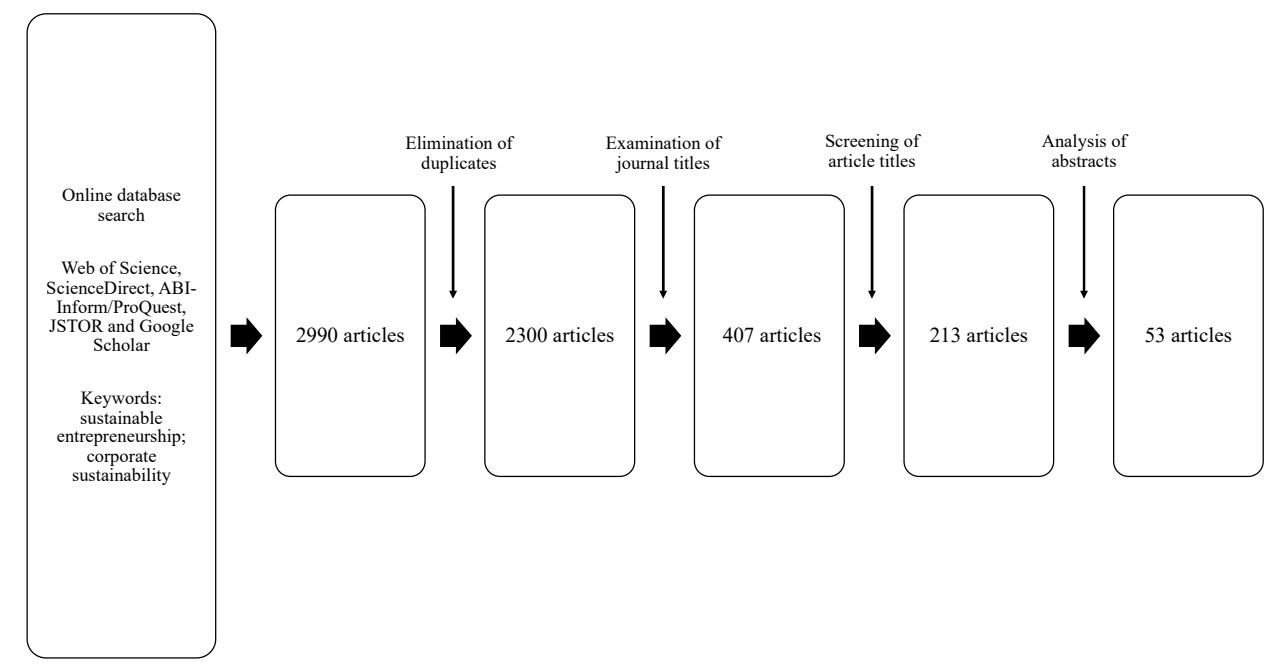

Figure 1. Systematic review process.

In a first step, the electronic databases Web of Science, ScienceDirect, ABI-Inform/ProQuest, JSTOR, and Google Scholar were systematically searched. In order to ensure a widespread search, the keywords used were "sustainable entrepreneurship" or "corporate sustainability". The scan was applied to the respective title, abstract, and keywords. The main focus was on journal articles published in ranked journals. The time frame of the search was limited to 1990-2017 (which also marks the end of the literature search for this paper). The search generated 2990 results, which were assessed in four ensuing steps. Next, duplicates and entries that were not journal articles were eliminated, leaving 2300 results for further review.

Third, the titles of the journals were examined, resulting in the elimination of papers published in journals that were not relevant for the purpose of this study (e.g., Conservation Biology), following our goal of providing purely the entrepreneur's point of view. Conducting this second step left 407 research articles for consideration. In a fourth step, the titles of the journal articles were screened, resulting in the exclusion of articles that did not fit the matter of this research. The fifth step involved reading 
the abstracts of the remaining 213 articles, and analysing them regarding their research question and study approach. As the aim of this paper is to provide an overview of factors facilitating responsible managerial practices, the criteria for the papers chosen for the final review was that the research was focused on or included the investigation of factors influencing the sustainable entrepreneurship orientation (SEO). Within the fifth step, journal articles whose foci did not fit the focus of this thesis were eliminated, resulting in a final set of 53 articles.

Next, the remaining 53 articles were further analysed and clustered based on the said analysis. In this paper, we adopt Spence et al.'s [25] analytical structure to review literature and cluster articles according to their level of analysis. Namely, theses level of analyses include the individual level (including personality traits or characteristics, belief systems, values, and personal capabilities and skills), the organizational level (degree of formalization of sustainable development, strategic orientation, relationship with stakeholders and company culture), and the contextual level (isolating factors influencing the company to act sustainably).

In order to present a transparent and consistent method of reviewing, the final set of articles is listed in the Appendix A in Table A1, to highlight the selection of the independent variables. Regarding the distribution of the reviewed articles, over time it can be said that $7.55 \%$ of them were published between 1996-2000, 20.75\% between 2001 and 2005, 28.30\% between 2006 and 2010, 35.85\% between 2011 and 2015, and 7.55\% between 2016 and 2017 (Figure 2). This indicates that recent years have seen an increased interest in the research field examined.

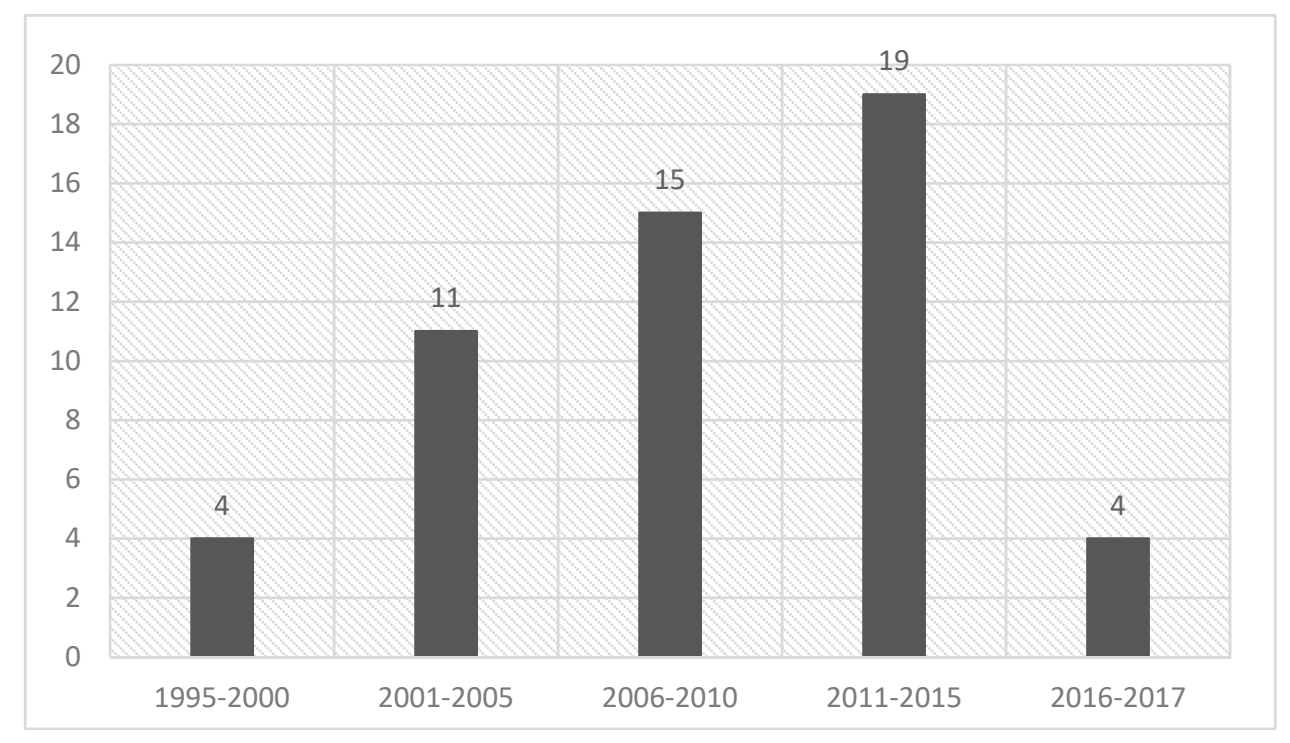

Figure 2. Reviewed articles per period of publication.

After an extensive analysis of the articles, important concepts shaping the sustainable entrepreneurial orientation could be extracted. To present a comprehensive understanding of the concepts introduced in the literature review of this research, the information extracted from the final set of the literature review are supported by additional sources. First, the closed-circle system was applied, for which relevant references cited in the remaining set of articles were also examined, and important findings used to refine the final argumentation. Second, other relevant research papers were used to introduce more general entrepreneurship concepts, such as entrepreneurial orientation (EO).

\section{Results: Sustainable Entrepreneurial Orientation and the Factors that Facilitate Responsible Managerial Practices}

Sustainable entrepreneurship in existing firms, especially SMEs, is led by an entrepreneur who carries out managerial sustainable practices (MSP) through innovation and by creating 
value [6]. These entrepreneurially-sustainable practices manifest sustainable entrepreneurship within an organization $[17,36,68,71,73-76]$. While research has strongly developed over the past years, there remains a lack of consensus when it comes to classifying these sustainable entrepreneurial orientation practices.

As mentioned, the clustering of the articles was based on Spence et al.'s [25] analytical structure of dividing the influencing factors into individual, organizational, and contextual factors. The final set of clusters is illustrated in Figure 3, showing the reviewed articles clustered according to their level of analysis. The summarized findings of this literature review are presented in the following paragraphs.

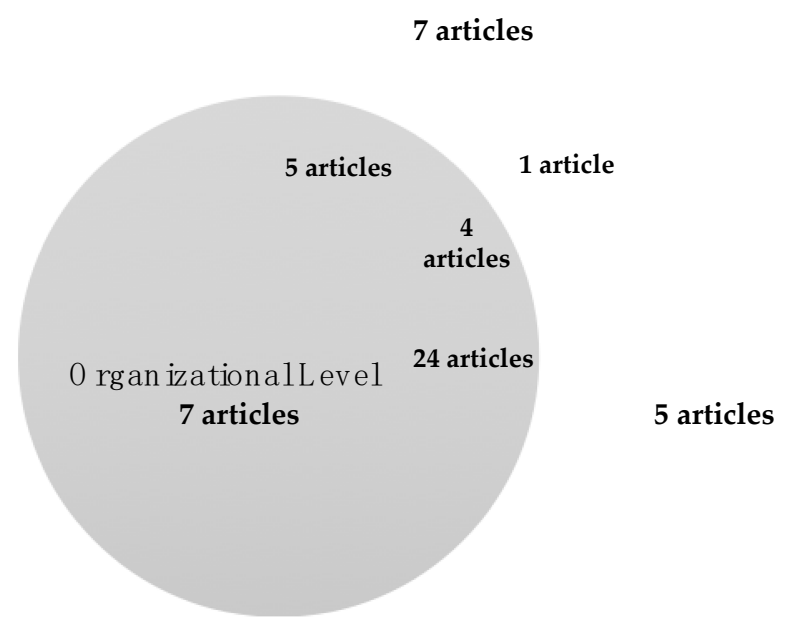

Figure 3. Reviewed articles clustered per their level of analysis.

\subsection{Individual Level}

Brem, Bhattacharjee, and Jahanshahi highlight how entrepreneurs show a more sustainablyoriented set of entrepreneurial actions when their belief in a just world is strong [77]. Managers who possess a strong belief in a just world tend to avoid unethical behaviour when it directly influences other people at their workplace, and therefore prefer a more ethical style of decision making, as shown by previous studies [78]. When it comes to the individual level of the single entrepreneur, the existing literature suggests that sustainable entrepreneurs are value-driven, while enterprises that are established and run based on particular individual values include, but are not limited to, sustainability $[79,80]$. Based on the above-mentioned values, sustainable entrepreneurs commit themselves and their firms to an effort towards a unique, outstanding, competitive position. They also want to reach a certain level of efficiency in the three areas of sustainability. The common characteristic(s) typically held by social and environmental entrepreneurs can also be applied to sustainable entrepreneurs, who can be described as "change agents", implying a certain disagreement with prevailing existing paradigms. They also communicate a desire to implement a more long-term focus, limiting themselves to doing more with fewer inputs [12,81]. Personality characteristics also contribute to the likelihood of effective leadership. With these, it has been found that environmental leaders working for both non-profit and for-profit organizations achieve more favourable outcomes than their conventional counterparts at other organizations when it comes to the "need for achievement", "need for affiliation", "self-confidence", as well as "emotional maturity" [79]. Furthermore, when taking an even closer, more finite look at the differences between social and conventional entrepreneurs, social entrepreneurs are more likely to be described as charismatic, highly skilled, and showing a high degree of initiative. This stands in contrast to the conventional entrepreneur, who can be characterised as "pragmatic", "opportunistic", and "imitating". All of this indicates the potential competitive advantages of non-conventional entrepreneurs [82]. An additional potential competitive advantage of sustainable entrepreneurs is the increased level of persistence they 
display when compared to conventional entrepreneurs. This allows them to maintain an overview and "stay in the loop" at all times, despite the minor and major obstacles they face as part of their business operations [82]. The contingency characteristic of sustainable entrepreneurs furthermore enables them to successfully adapt to changing environmental parameters, acclimating to new circumstances and exploiting new opportunities as they do so [12].

The personality characteristics described above form a theoretically solid starting point for an analysis of the distinguishing characteristics of sustainable entrepreneurs, and the effect of these traits on the expected success of these entrepreneurs $[25,66,83]$. However, the puzzle of success consists of additional elements when it comes to successfully engaging in sustainable entrepreneurship. As Tilley and Young conclude, owner-managers are required to have personal values and beliefs that are motivated by, align with, and are an extension of sustainable principles [84]. These include (but are not limited to) the values of social and environmental entrepreneurs that are based on altruism. This distinguishes them from conventional entrepreneurs, where the need of others (including nature) is put ahead of the needs of the entrepreneurs themselves $[81,85]$. However, the principles mentioned do not exclude the common components found in traditional entrepreneurial processes. In the case of environmental leaders [79], an optimal mix of leadership styles is required, thus necessitating not only well-argued values, but rational inputs as well, not to mention the taken-for-granted rules and norms as the motives of sustainable entrepreneurship on the individual level.

To sum up, research has shown that sustainable entrepreneurs tend to derive their will to act more sustainably from their personal values or traits. These findings are consistent with the "upper echelons theory" which states that the strategic actions of entrepreneurs inherently reflect their values, beliefs, and orientations [86,87]. While there is great merit to this research, we argue that more research is needed to better understand the nature of practices that founders or leaders of sustainable enterprises adopt in order to ensure sustainable entrepreneurial orientation throughout their enterprises.

\subsection{Organizational Level}

Sustainable enterprises ensure sustainable entrepreneurial orientation on a voluntary, albeit formalized and integrated basis. The formalized aspect of the sustainable enterprise can be concretised by the implementation of certain types of control systems and reporting procedures, as well as the formal style of tracking the progress of the entity's sustainable practices [75]. However, the formal aspects of the sustainable enterprise tend to be counterintuitive and potentially disadvantageous to how SMEs are normally observed and assessed [88], as SMEs tend to practice sustainability in a "blind" manner, not knowing how their actions could theoretically and practically contribute to a generally sustainable outcome [25]. According to the literature, a sustainable entrepreneurial orientation in firms, or even making sustainability the core foundation of enterprises, could potentially be hazardous. In other words, the formalized aspect of sustainable firms goes against the widespread assumption of SMEs being characterized by a small degree of formalization, as well as the intuitive management style these firms are likely to display [25]. With this being said, the formalization aspect of SMEs has in fact undergone a transformation regarding the reporting standards and management practices applied within organizations. New SME research shows that enterprises have adopted more formalized management approaches, as well as the implementation of quality standards [89].

In addition to the degree of formalization, the corporate behaviour of firms is deemed a critical component in SMEs, with their sustainable behaviour specifically constituting the relevant foundation on which sustainable entrepreneurship can be carried out successfully. According to Covin and Slevin [39], as well as Knight [90], the sustainable behavioural aspect of entrepreneurship theory can be defined as the pro-activeness, innovativeness, and risk-taking ability of enterprises. The idea that sustainable enterprises need to be proactive, innovative, and risk-taking $[17,41,91]$, while being aware of and conscious about the environment [51], was formerly seen as the combination of sustainable and entrepreneurial orientations, as well as the overall strategic orientation of a sustainable entrepreneurial approach [71]. At the core of SMEs lies the driving force to move forward and excel in markets, 
constituting the willingness and pro-activeness to go beyond borders, and discover and conquer new markets. Here, innovation is the outcome of this proactivity, which in turn is a driving force for the establishment and integration of formalized sustainable practices [81,92]. As mentioned, sustainable entrepreneurship is a long-term, relatively risky endeavour. Its scope tends to look further down the road, therefore requiring a relatively large degree of patience and a longer-than-conventional waiting period until a healthy return on investments can be achieved. As the sustainability market is still in a relatively young stage of development, with customers not translating their sustainable desires into purchases frequently enough, entrepreneurs are required to and are taking moderate or calculated risks, despite sustainable entrepreneurs being long-term-oriented and risk-averse, due to their volatile stream of revenues [93]. This implies the need for risk-limiting techniques and processes.

Firms vary in age and size. This means they also vary in their resource combinations [94,95]. Katz and Gartner argue that when founding and growing a new enterprise, a crucial factor is identifying and acquiring resources [96]. The entrepreneurship literature emphasises how liabilities of smallness and resource constraints in firms can be mitigated through social capital [97]. This makes social and financial networks particularly important for access to a diverse set of both tangible and intangible resources [98]. Access to these kinds of networks is especially crucial, due to how they can take on several important functions, such as the connection of entrepreneurs to information services. This is why they are so important for sustainable entrepreneurs and the companies they are managing. A connection to these services provides access to capital, low-cost support services, and infrastructure that enables entrepreneurs to share ideas and resources with each other, not to mention the opportunity to strengthen local entrepreneurial culture $[99,100]$. Current literature on ecologically-sustainable entrepreneurship stresses how sustainable entrepreneurs need to create and alter relationships with external stakeholders. As mentioned above, entrepreneurs have to be able to influence opinion leaders and key actors to get the most out of their capability of establishing [101] and modifying powerful relationships among different actors [102]. This need helps make clear the critical nature of ecologically-sustainable entrepreneurs with their external environment [73,103-105]. Here, there is no recognizable further distinction or separation between formal and informal institutions [106-108], nor is there cooperation and mutual support in networks [109-111]. Research shows that entrepreneurs leading sustainable enterprises maintain sustainable growth in pursuit of their long-term survival by being more inclined towards successful networking within and across industries [81,112].

This kind of relationship development between internal and external partners tends to help sustainable entrepreneurs be on the cutting edge of their market. They are among the first to identify new, sustainable business opportunities that are most likely to lead to a reliable source of income and have the potential to earn a higher profit than other firms [113]. Because it involves a certain degree of risk, which is specifically caused by the unexplored direction a firm is planning on exploring, this strategy of defining front-line opportunities and tackling them as "first movers" in the general market economy has to be defined as "proactive" [114,115].

Summarizing, we can conclude that an SME's internal culture and the reconfiguration of resources [116] are critical determinants for adopting a sustainable entrepreneurial orientation. A potential lack of acceptance of sustainable development principles can lead to institutional isolation, as the resources needed for sustainable development may not be adequately mobilized [117], thus requiring a supportive internal culture and external support, in the form of networks or agents, to enable a sustainable entrepreneurial orientation. While there is research emerging because of increasing transparency, there is still a need to understand ethical dimensions when it comes to developing close relations with external, supportive partners. For example, who owns the intellectual property rights of the jointly created outputs? Where does responsibility lie when things go wrong? What is the proper division of labour? Finally, how does sustainable entrepreneurial orientation impact company performance? 


\subsection{Contextual/Market Level}

In addition to the organizational and individual factors, contextual factors are deemed as having an important influence on the success of firms. After all, the environment from which that success operates is of critical importance for the overall degree of success when implementing an entrepreneur's project [118]. Traditional theories of the competitive dimension of a firm emphasize the significance of the owner-manager construction in strategic decision-making $[49,119]$, underestimating the importance of the wider context on a firm; this is a "gap" that neo-institutional theory is filling. The context in which firm operates, even when assumed to be unfavourable at first glance, could in fact possess new opportunities for firms when approached actively, as is the case with citizens' trust towards public policies, specifically regarding environmental laws [120]. As Gast et al. point out, there are four dominant impulses for enterprises to implement sustainable entrepreneurship: "regulation, public concern, expected competitive advantage, and top management commitment" [6] (p. 46).

We live in a global setting, where growth through entrepreneurship as well as the striving for and achievement of sustainable development is fostered by (supra-) national as well as local governments [71]. Attaining opportunities at the intersection of sustainable development and entrepreneurship is a major challenge for organizations throughout all levels on the global, regional, and local scales [121]. To avoid the complete loss of the numerous economic, social, and natural resources society currently possesses, steps have to be taken to reverse their depletion.

Another powerful external motive for conducting business more sustainably includes the public concern expressed, e.g., by consumer behaviour. As Prothero et al. point out, participating in CSR is generally very socially and ecologically sustainable [122]. This makes the perceived value of sustainability, as it regards CSR issues, a potentially key factor in the willingness of people to consume more consciously. An increase in perceived value is an important factor companies consider when making the decision to act more sustainably [123]. In their paper, Wang and Ho introduce the idea that true sustainability solutions are to be found within the emerging domain of the sharing economy, where access to rather than owning an asset contributes and becomes the key to economic growth, scale advantages, and profits [123]. The authors base this idea on Brahme, who concludes in his article that the true solution to sustainability is actually not found within CSR and its practitioners [124]. Important here is that this does not imply that CSR should be dismissed as such. According to Tian, Wang, and Yang, companies are "obliged" to a certain extent to facilitate and achieve a fundamental level of economic and legal CSR, and should therefore not neglect it's importance, because the sharing economy model enables a two-way avenue to higher levels of CSR practice and ethical and philanthropic responsibilities [100]. Morever, an increase in customer perception can be linked to an improvement in terms of reputation; considering reputation as a strategic asset, Pineiro-Chousa et al. have introduced the concept of using the implementation of sustainable practices as a suitable risk-hedging strategy $[125,126]$.

The rise in the perceived value of the product can also be considered a competitive advantage. As Lordkipandize et al. point out, a competitive advantage in terms of cost reduction, or the perceived value of the product, which raises the likelihood of the consumer to buy the product, is likely to be achieved by a focus on environmental sustainability [127]. This rise in perceived value or cost reduction of the product can be accomplished by implementing more sustainable measures in terms of sourcing, production, etc., towards innovative changes facilitating more ecological sustainability.

The profit-generating potential for the enterprise and its stakeholders justifies the risks involved in creating societal value. This contribution to socio-economic development [128], is seen as being enabled by a potential change in the environmentally- and sustainability-oriented thinking of sustainable firms [76,83,129-132]. These kinds of firms are understood as promoting a greener future by acting as role models $[30,128,133]$. To put it differently, Tiley and Young describe these firms as "wealth generators of the future" [84] (p. 79). Being a role model is reflected in these firms' solution-providing orientation. They deliver solutions to environmental challenges and ecological decay $[74,134]$ via eco-innovations [6,91]. In doing this, they advocate a transition towards more sustainable methods of 
production and consumption [68,92]. Activating and mobilizing key actors within a community can also dramatically contribute to a change in consumer mind-sets, not to mention enterprises and their surrounding environments [131]. An example of this would be the organization of a special community event, such as waste recycling training, with the objective of creating and increasing awareness of consumer habits and consumption patterns, developing an interest in local products, and promoting the use of sustainable design and consumption [130].

We can finally state that researchers have focused on a better understanding of how entrepreneurs can help society and the environment through sustainable entrepreneurship, and how they can act as role models or change agents, in light of the fact that sustainable consumption or investing and financing based on sustainability is still in its infancy. To really understand the role of entrepreneurs in driving social change, we need more research that identifies the links between organizational and contextual levels. How do these different levels interact? What practices can be derived? How do external partners and sustainable enterprises need to interact, in order to create eco-systems that facilitate social or ecological change?

\subsection{Limitations}

Evidently, this review has limitations that need to be acknowledged. First, while this article is comprehensive in its kind, the literature review approach applied could be criticized for taking a reduced selection of publications as a base for further analysis, and therefore not including all the relevant work on sustainable entrepreneurship. Namely, the review could be said to focus too much on the managerial aspect of sustainable entrepreneurship orientation. Nevertheless, the systematic literature review procedure applied enables us to form a literature base representing the status-quo research on facilitating factors of responsible managerial practices as completely as possible within the sustainable entrepreneurship research. Thus, the probability of having excluded critical studies with findings that would have strongly altered this paper's conclusion is restricted.

Another limitation is the missing segregation of papers investigating enterprises founded based on the premises of sustainability, e.g., start-ups with eco-innovations and articles researching companies implementing sustainable managerial practices. This missing differentiation is also reflected in the chosen key words of "sustainable entrepreneurship" and "corporate sustainability". This can be justified with the intention of providing an extensive overview of the status-quo research on influencing factors of sustainable entrepreneurship orientation, which made it necessary to broaden the initial search. However, investigating whether there is a difference in factors influencing SEO could be a potentially interesting topic for further research.

Moreover, we acknowledge the limitations regarding the objectivity of the analysis results. Evidently, the allocation of the main focus, the selection of data, and the interpretation of the results are subjective. In order to minimize the bias, the multiple assessor method was applied.

\section{Conclusions: Relevance for Theory and Practice and Recommendations for Further Research}

In this article, we contribute to existing literature by providing a structured literature review of identifying factors that facilitate responsible managerial practices. This is relevant to understand and develop a more sustainable financial system. Financial academic literature has shown that ESG investments are equally profitable, or only slightly underperforming, depending on the researched area. While there are no official selling numbers, the pure increase of offered products and indices shows that ESG investments are well-sold by the financial industry, and therefore that the demand of ESG products is significant. With the rising importance for society and companies alike to act sustainably in terms of social, economic and ecological capital [9], this paper contributes to both theory and practice, by introducing factors that facilitate sustainable responsible practices on the entrepreneur's side, and connecting the findings with existing financial research.

These responsible managerial practices were located on the individual, organizational, and contextual level. Figure 3 indicates that some research exclusively puts its focus on one level, 
whereas other research considers the relation between two levels more extensively. On each level, we identified the following possible research avenues:

From an individual perspective, this research has great value. This is why we argue that more of it is needed to better understand the antecedents of practices (e.g., training as put forward by Azeez Olugbola [135]) or the nature of practices that founders or leaders of sustainable enterprises adopt, in order to ensure sustainable entrepreneurial orientation throughout their enterprises.

On the organizational level, investigations towards fully understanding the ethical dimensions when it comes to developing close relations with external, supportive partners are evidently needed. While there is research emerging, due to greater transparency, there is still a need to achieve a deeper understanding of the ethical dimensions when it comes to developing close relations with external, supportive partners. Some examples here include: Who owns the intellectual property rights of the jointly created outputs? Where does responsibility lie when things don't run as planned? What is the proper division of labour? Another research stream would be to investigate closer the relationship between corporate ethical practices and corporate financial performance, as put forward by Cuomo et al. [136]. These are just a few of the questions that would allow deeper, better insight.

Finally, we also propose to provide more joint analyses of entrepreneurs and investors concerning environmental, social, and sustainable business, e.g., through the use of configuration analyses (see e.g., [137]). It is important to analyse and compare their respective expectations from each other, joint goals, and the drivers of perceived risk, on the way to developing a more sustainable financial system. Furthermore, to really understand the role of entrepreneurs in driving social change [138]. further research will have to identify the links between organizational and contextual levels. How do these different levels interact? What practices can be derived? How do external partners and sustainable enterprises need to interact to create the ecosystems that facilitate social or ecological change?

Author Contributions: All authors participated in the writing process itself in almost equal parts, the sequence of authors reflecting the respective contribution to the article. Janina Burtscher undertook the literature review/analysis.

Conflicts of Interest: The authors declare no conflict of interest.

\section{Appendix A}

Table A1. Overview of Reviewed Articles.

\begin{tabular}{|c|c|c|c|c|}
\hline Title & Author & Year & Journal & Level of Analysis \\
\hline $\begin{array}{l}\text { Who takes more } \\
\text { sustainability-oriented } \\
\text { Entrepreneurial Actions? } \\
\text { The Role of Entrepreneurs' Values, } \\
\text { Beliefs and Orientations. }\end{array}$ & $\begin{array}{l}\text { Brem, Bhattacharjee } \\
\text { \& Jahanshahi }\end{array}$ & 2017 & Sustainability & Individual \\
\hline $\begin{array}{l}\text { Bad Apples in Bad Barrels } \\
\text { Revisited: Cognitive Moral } \\
\text { Development, Just World Beliefs, } \\
\text { Rewards, and Ethical } \\
\text { Decision-Making. }\end{array}$ & $\begin{array}{l}\text { Ashkanasy, N.M., } \\
\text { Windsor, C.A., \& } \\
\text { Treviño, L.K. }\end{array}$ & 2006 & $\begin{array}{l}\text { Business Ethics } \\
\text { Quarterly }\end{array}$ & Individual \\
\hline $\begin{array}{l}\text { Toward a Typology of New } \\
\text { Venture Creators: Similarities and } \\
\text { Contrasts Between Business and } \\
\text { Social Entrepreneurs }\end{array}$ & $\begin{array}{l}\text { Vega, G., \& } \\
\text { Kidwell, R.E. }\end{array}$ & 2007 & $\begin{array}{l}\text { New England } \\
\text { Journal of } \\
\text { Entrepreneurship }\end{array}$ & Individual \\
\hline $\begin{array}{l}\text { What motivates ecopreneurs to } \\
\text { start businesses? }\end{array}$ & $\begin{array}{l}\text { Kirkwood, J., \& } \\
\text { Walton, S. }\end{array}$ & 2010 & $\begin{array}{l}\text { International Journal } \\
\text { of Entrepreneurial } \\
\text { Behavior \& Research }\end{array}$ & Individual \\
\hline $\begin{array}{l}\text { The Meaning of "Social } \\
\text { Entrepreneurship" }\end{array}$ & Dees & 2001 & Book & $\begin{array}{c}\text { Individual/Organizational/ } \\
\text { Contextual }\end{array}$ \\
\hline
\end{tabular}


Table A1. Cont.

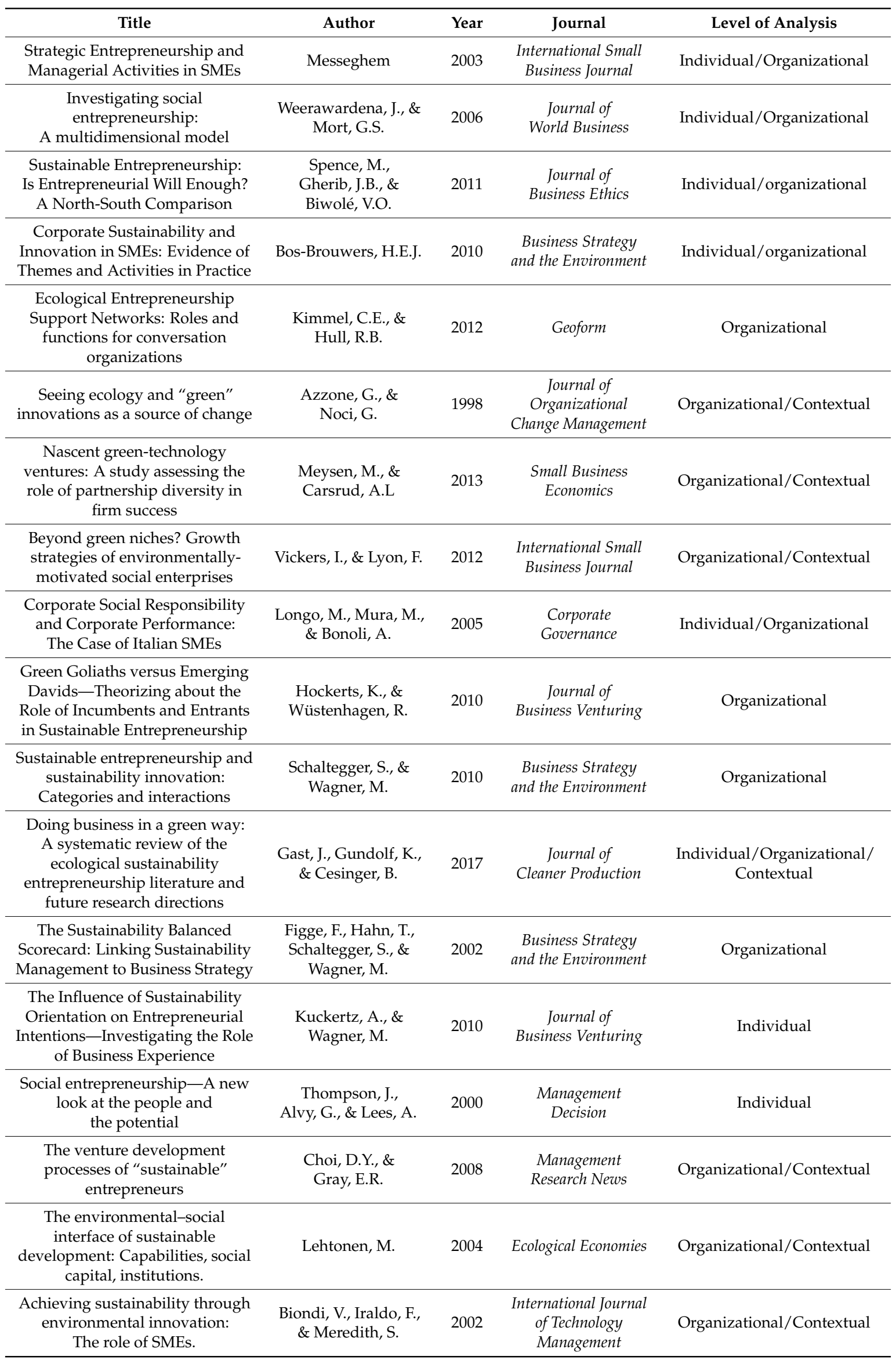


Table A1. Cont.

\begin{tabular}{|c|c|c|c|c|}
\hline Title & Author & Year & Journal & Level of Analysis \\
\hline $\begin{array}{l}\text { Family and Territory Values for a } \\
\text { Sustainable Entrepreneurship: } \\
\text { The Experience of Loccioni Group } \\
\text { and Varnelli Distillery in Italy }\end{array}$ & Del Baldo, M. & 2012 & $\begin{array}{l}\text { Journal of Marketing } \\
\text { Development and } \\
\text { Competitiveness }\end{array}$ & Indivdual \\
\hline $\begin{array}{l}\text { Sustainability through food and } \\
\text { conversation: The role of an } \\
\text { entrepreneurial restaurateur in } \\
\text { fostering engagement with } \\
\text { sustainable development issues. }\end{array}$ & $\begin{array}{l}\text { Moskwa, E., } \\
\text { Higgins-Desbiolles, F., } \\
\text { \& Gifford, S. }\end{array}$ & 2015 & $\begin{array}{c}\text { Journal of } \\
\text { Sustainable Tourism }\end{array}$ & Organizational/Contextual \\
\hline $\begin{array}{l}\text { Ecological entrepreneurship: } \\
\text { Sustainable development in local } \\
\text { communities through quality food } \\
\text { production and local branding. }\end{array}$ & $\begin{array}{l}\text { Marsden, T., \& } \\
\text { Smith, E. }\end{array}$ & 2005 & Geoform & Organizational/Contextual \\
\hline $\begin{array}{c}\text { Sustainability Entrepreneurship } \\
\text { and Equitable Transitions to a } \\
\text { Low-Carbon Economy }\end{array}$ & $\begin{array}{l}\text { Parrish, B.D., \& } \\
\text { Foxon, T.J. }\end{array}$ & 2006 & $\begin{array}{c}\text { Greener } \\
\text { Management } \\
\text { International }\end{array}$ & Organizational/Contextual \\
\hline $\begin{array}{c}\text { Supporting Green } \\
\text { Entrepreneurship in Romania: } \\
\text { Imperative of Sustainable } \\
\text { Development }\end{array}$ & Zamfir, P.B. & 2014 & $\begin{array}{l}\text { Romanian Economic } \\
\text { and Business Review }\end{array}$ & Organizational/Contextual \\
\hline $\begin{array}{c}\text { Sustainability } \\
\text { entrepreneurs-Could they be the } \\
\text { True Wealth Generators of } \\
\text { the Future? }\end{array}$ & $\begin{array}{l}\text { Tilley, F., \& } \\
\text { Young, W. }\end{array}$ & 2006 & $\begin{array}{c}\text { Greener } \\
\text { Management } \\
\text { International }\end{array}$ & Individual/Contextual \\
\hline $\begin{array}{l}\text { Shaping the future: Sustainable } \\
\text { innovation and entrepreneurship. }\end{array}$ & Belz, F.M. & 2013 & Social Business & Organizational/Contextual \\
\hline $\begin{array}{l}\text { The transition to the } \\
\text { sustainable enterprise }\end{array}$ & Keijzers, G. & 2002 & $\begin{array}{l}\text { Journal of Cleaner } \\
\text { Production }\end{array}$ & Organizational/Contextual \\
\hline $\begin{array}{l}\text { Sustainable Innovation through } \\
\text { an Entrepreneurship Lens }\end{array}$ & Larson, A.L. & 2000 & $\begin{array}{l}\text { Business Strategy } \\
\text { and the Environment }\end{array}$ & Organizational \\
\hline $\begin{array}{l}\text { Environmental Entrepreneurship } \\
\text { in Organic Agriculture in Järna }\end{array}$ & Larson, A.L. & 2012 & $\begin{array}{l}\text { Journal of } \\
\text { Sustainable } \\
\text { Agriculture }\end{array}$ & Organizational/Contextual \\
\hline $\begin{array}{l}\text { Urban development projects } \\
\text { catalyst for sustainable } \\
\text { transformations: The need for } \\
\text { entrepreneurial } \\
\text { political leadership. }\end{array}$ & $\begin{array}{l}\text { Block, T., \& } \\
\text { Paredis, E. }\end{array}$ & 2013 & $\begin{array}{l}\text { Journal of Cleaner } \\
\quad \text { Production }\end{array}$ & Organizational/Contextual \\
\hline $\begin{array}{l}\text { Entrepreneurship, management, } \\
\text { and sustainable development. }\end{array}$ & $\begin{array}{l}\text { Ahmed, A., \& } \\
\text { McQuaid, R.W. }\end{array}$ & 2005 & $\begin{array}{l}\text { World Review of } \\
\text { Entrepreneurship, } \\
\text { Management and } \\
\text { Sustainable } \\
\text { Development }\end{array}$ & Organizational/Contextual \\
\hline
\end{tabular}


Table A1. Cont.

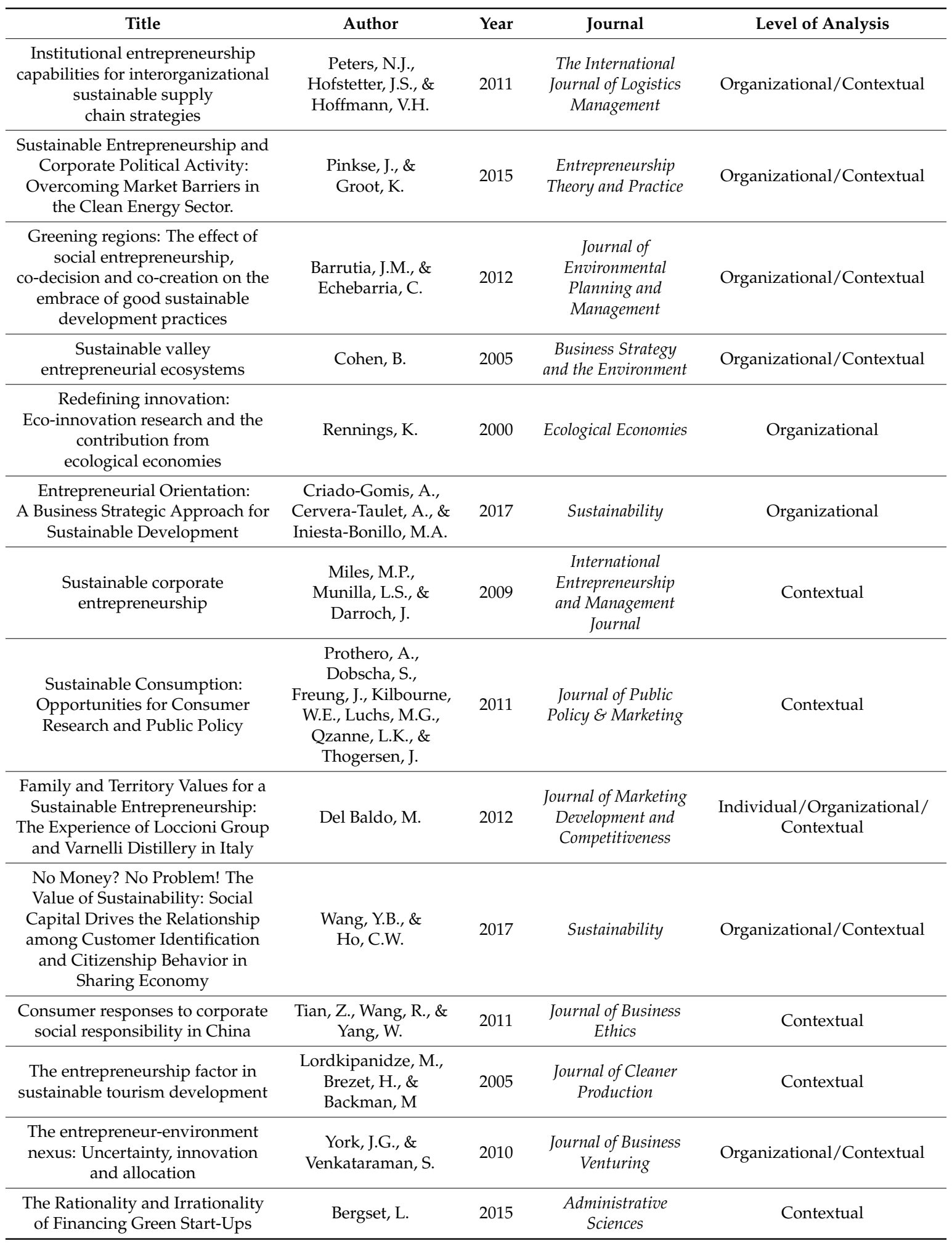

\section{References}

1. Archarya, V.V.; Richardson, M. Causes of the Financial Crisis. J. Politics Soc. 2009, 21, 195-210.

2. Friede, G.; Busch, T.; Bassen, A. ESG and financial performance: Aggregated evidence from more than 2000 empirical studies. J. Sustain. Financ. Invest. 2014, 5, 210-233. [CrossRef] 
3. Guenster, N.; Bauer, R.; Derwall, J.; Koedijk, K. The Economy Value of Corporate Eco-Efficiency. Eur. Financ. Manag. 2011, 17, 679-704. [CrossRef]

4. Hall, J.; Daneke, G.; Lenox, M. Sustainable development and entrepreneurship: Past contributions and future directions. J. Bus. Ventur. 2010, 25, 439-448. [CrossRef]

5. Fellnhofer, K.; Kraus, S.; Bouncken, R.B. The Current State of Research on Sustainable Entrepreneurship. Int. J. Bus. Res. 2014, 14, 163-172. [CrossRef]

6. Gast, J.; Gundolf, K.; Cesinger, B. Doing business in a green way: A systematic review of the ecological sustainability entrepreneurship literature and future research directions. J. Clean. Prod. 2017, 147, 44-56. [CrossRef]

7. Schumpeter, J.A. The Theory of Economic Development; Harvard University Press: Cambridge, MA, USA, 1934.

8. Cohen, B.; Winn, M.I. Market imperfections, opportunity and sustainable entrepreneurship. J. Bus. Ventur. 2007, 22, 29-49. [CrossRef]

9. Melay, I.; Kraus, S. Green Entrepreneurship: Definition of Related Concepts. Int. J. Strateg. Manag. 2012, 12, 1-12.

10. Berle, G. The Green Entrepreneur: Business Opportunities That Can Save the Earth and Make You Money; Liberty Hall Press: Blue Ridge, PA, USA, 1991.

11. Allen, J.C.; Malin, S. Green Entrepreneurship: A Method for Managing Natural Resources? Soc. Nat. Resour. 2008, 21, 828-844. [CrossRef]

12. Dees, J.G. The Meaning of Social Entrepreneurship; Standford University: Standford, CA, USA, 2001.

13. Mair, J.; Marti, I. Social entrepreneurship research: A source of explanation, prediction, and delight. J. World Bus. 2006, 41, 36-44. [CrossRef]

14. Smith, W.K.; Gonin, M.; Besharov, M.L. Managing Social-Business Tensions. Bus. Ethics Q. 2013, 23, 407-442. [CrossRef]

15. Moss, T.W.; Short, J.C.; Payne, G.T.; Lumpkin, G.T. Dual identities in social ventures: An exploratory study. Entrep. Theory Pract. 2011, 35, 805-830. [CrossRef]

16. Isaak, R. Green Logic: Ecopreneurship, Theory and Ethics; Routledge: West Hartford, CT, USA, 1998.

17. Schaltegger, S.; Wagner, M. Sustainable entrepreneurship and sustainability innovation: Categories and interactions. Bus. Strategy Environ. 2010, 20, 222-237. [CrossRef]

18. Vallaster, C. Managing a Company Crisis through Strategic Corporate Social Responsibility: A Practice-based Analysis. Corp. Soc. Responsib. Environ. Manag. 2017, 24, 509-523. [CrossRef]

19. McWilliams, A.; Siegel, D.; Wright, P.M. Corporate Social Responsibility: Strategic Implications. J. Manag. Stud. 2006, 43, 1-18. [CrossRef]

20. Orlitzky, M.; Siegel, D.S.; Waldman, D.A. Strategic Corporate Social Responsibility and Environmental Sustainability. Bus. Soc. 2011, 50, 6-27. [CrossRef]

21. Peloza, J.; Shang, J. How can corporate social responsibility activities create value for stakeholders? A systematic review. J. Acad. Mark. Sci. 2011, 39, 117-135. [CrossRef]

22. Bruyaka, O.; Zeitzmann, H.; Chalamon, I.; Wokutch, R.; Thakur, P. Strategic corporate social responsibility and orphan drug development: Insights from the US and the EU biopharmaceutical industry. J. Bus. Ethics 2013, 117, 45-56. [CrossRef]

23. Acquier, A.; Valiorgue, B.; Daudigeos, T. Sharing the shared value: A transaction cost perspective on strategic CSR policies in global value chains. J. Bus. Ethics 2017, 144, 139-152. [CrossRef]

24. Kolk, A.; Mauser, A. The Evolution of Environmental Management: From Stage Models to Performance Evaluation. Bus. Strategy Environ. 2002, 11, 14-31. [CrossRef]

25. Spence, M.; Gherib, J.B.; Biwolé, V.O. Sustainable Entrepreneurship: Is Entrepreneurial Will Enough? A North-South Comparison. J. Bus. Ethics 2011, 99, 335-367. [CrossRef]

26. Brown, S.; Lugo, A.E. Rehabilitation of Tropical Lands: A Key to Sustaining Development. Restor. Energy 1994, 2, 97-111. [CrossRef]

27. Daly, H.E.; Cobb, J.B.; Cobb, C.W. For the Common Good: Redirecting the Economy toward Community, the Environment, and a Sustainable Future; Beacon Press: Boston, MA, USA, 1994.

28. Littig, B.; Griessler, E. Social sustainability: A catchword between political pragmatism and social theory. Int. J. Sustain. Dev. 2005, 8, 65-79. [CrossRef]

29. International Labour Office. Report VI: The Promotion of Sustainable Enterprises, International Labour Conference-96th Session; International Labour Office: Geneva, Switzerland, 2007. 
30. Choi, D.Y.; Gray, E.R. The venture development processes of "sustainable" entrepreneurs. Manag. Res. News 2008, 31, 558-569. [CrossRef]

31. Harrison, J.; Freeman, R. Stakeholders, social responsibility, and performance: Empirical evidence and theoretical perspectives. Acad. Manag. J. 1999, 42, 479-485. [CrossRef]

32. Waddock, S.; Smith, N. Corporate social responsibility audits: Doing well by doing good. Sloan Manag. Rev. 2000, 41, 75-83.

33. Carroll, A.B. The pyramid of corporate social responsibility: Toward the moral management of organizational Stakeholders. Bus. Horiz. 1991, 34, 39-48. [CrossRef]

34. Carroll, A.B. A three-dimensional conceptual model of corporate performance. Acad. Manag. Rev. 1979, 4, 497-505.

35. Mohr, L.A.; Webb, D.J.; Harris, K.E. Do consumers expect companies to be socially responsible? The impact of corporate social responsibility on buying behavior. J. Consum. Aff. 2001, 35, 45-72. [CrossRef]

36. Lozano, R.; Carpenter, A.; Huisingh, D. A review of 'theories of the firm' and their contributions to Corporate Sustainability. J. Clean. Prod. 2015, 106, 430-442. [CrossRef]

37. Kramer, M.R.; Porter, M.E. Creating shared value. Harv. Bus. Rev. 2011, 89, 62-77.

38. Kraus, S.; Rigtering, J.C.; Hughes, M.; Hosman, V. Entrepreneurial orientation and the business performance of SMEs: A quantitative study from the Netherlands. Rev. Manag. Sci. 2012, 6, 161-182. [CrossRef]

39. Covin, J.G.; Slevin, D.P. Strategic management of small firms in hostile and benign environments. Strateg. Manag. J. 1989, 10, 75-87. [CrossRef]

40. Huarng, K.H.; Yu, T.H.K. Entrepreneurship, process innovation and value creation by a non-profit SME. Manag. Decis. 2011, 49, 284-296. [CrossRef]

41. Miller, D. The correlates of entrepreneurship in three types of firms. Manag. Sci. 1983, 29, 770-791. [CrossRef]

42. Zahra, S.A. Predictors and financial outcomes of corporate entrepreneurship: An exploratory study. J. Bus. Ventur. 1991, 6, 259-285. [CrossRef]

43. Auer, B.R.; Schuhmacher, F. Do socially (ir)responsible investments pay? New evidence from international ESG data. Q. Rev. Econ. Financ. 2016, 59, 51-62. [CrossRef]

44. Huarng, K.H.; Ribeiro-Soriano, D.E. Developmental management: Theories, methods, and applications in entrepreneurship, innovation, and sensemaking. J. Bus. Res. 2014, 67, 657-662. [CrossRef]

45. Mas-Tur, A.; Ribeiro-Soriano, D. The level of innovation among young innovative companies: The impacts of knowledge-intensive services use, firm characteristics and the entrepreneur attributes. Serv. Bus. 2014, 8, 51-63. [CrossRef]

46. Klein Woolthuis, R.J.A. Sustainable entrepreneurship in the Dutch construction industry. Sustainability 2010, 2, 505-523. [CrossRef]

47. Dean, T.J.; McMullen, J.S. Toward a theory of sustainable entrepreneurship: Reducing environmental degradation through entrepreneurial action. J. Bus. Ventur. 2007, 22, 50-76. [CrossRef]

48. Kirzner, I.M. Competition and Entrepreneurship; University of Chicago Press: Chicago, IL, USA, 1973.

49. Freeman, R.E. Strategic Management: A Stakeholders Approach; Pitman: Boston, MA, USA, 1984.

50. Barnard, C. The Functions of the Executive; Harvard University Press: Cambridge, MA, USA, 1938.

51. Bos-Brouwers, H.E.J. Corporate Sustainability and Innovation in SMEs: Evidence of Themes and Activities in Practice. Bus. Strategy Environ. 2010, 19, 417-435. [CrossRef]

52. Urbano, D.; Toledano, N.; Ribeiro-Soriano, D. Socio-cultural factors and transnational entrepreneurship: A multiple case study in Spain. Int. Small Bus. J. 2011, 29, 119-134. [CrossRef]

53. Covin, J.G.; Lumpkin, G.T. Entrepreneurial orientation theory and research: Reflections on a needed construct. Entrep. Theory Pract. 2011, 35, 855-872. [CrossRef]

54. Covin, J.G.; Slevin, D.P. A conceptual model of entrepreneurship as firm behavior. Entrep. Crit. Perspect. Bus. Manag. 1991, 3, 5-28. [CrossRef]

55. Covin, J.G.; Miller, D. International entrepreneurial orientation: Conceptual considerations, research themes, measurement issues, and future research directions. Entrep. Theory Pract. 2014, 38, 11-44. [CrossRef]

56. Rauch, A.; Wiklund, J.; Lumpkin, G.T.; Frese, M. Entrepreneurial orientation and business performance: An assessment of past research and suggestions for the future. Entrep. Theory Pract. 2009, 33, 761-787. [CrossRef]

57. Lumpkin, G.T.; Dess, G.G. Clarifying the Entrepreneurial Orientation Construct and linking it to Performance. Acad. Manag. Rev. 1996, 21, 135-172. 
58. Eggers, F.; Kraus, S.; Jensen, S.H.; Rigtering, J.P.C. A comparative analysis of the entrepreneurial orientation/growth relationship in service firms and manufacturing firms. Serv. Ind. J. 2014, 34, 275-294.

59. Low, M.B.; MacMillan, I.C. Entrepreneurship: Past research and future challenges. J. Manag. 1988, 14, 139-161. [CrossRef]

60. Morris, M.H.; Kuratko, D.F.; Covin, J.G. Corporate Entrepreneurship E Innovation; Thomson Higher Education: Mason, OH, USA, 2008.

61. Miller, D.; Friesen, P.H. Strategy making and environment: The third link. Strateg. Manag. J. 1983, 4, $221-235$. [CrossRef]

62. Engelen, A.; Kubea, H.; Schmidt, S.; Flatten, C. Entrepreneurial orientation in turbulent environments: The moderating role of absorptive capacity. Res. Policy 2014, 43, 1353-1369. [CrossRef]

63. Matsuno, K.; Mentzer, J.T.; Ozsomer, A. The effects of entrepreneurial proclivity and market orientation on business performance. J. Mark. 2002, 66, 18-32. [CrossRef]

64. Gasser, S.M.; Rammerstorfer, M.; Weinmayer, K. Markowitz revisited: Social portfolio engineering. Eur. J. Oper. Res. 2017, 258, 1181-1190. [CrossRef]

65. Noble, C.; Sinha, R.K.; Kumar, A. Market orientation and alternative strategic orientations: A longitudinal assessment of performance implications. J. Mark. 2002, 66, 25-39. [CrossRef]

66. Kuckertz, A.; Wagner, M. The Influence of Sustainability Orientation on Entrepreneurial IntentionsInvestigating the Role of Business Experience. J. Bus. Ventur. 2010, 25, 524-539. [CrossRef]

67. Parboteeah, K.P.; Addae, H.M.; Cullen, J.B. Propensity to support sustainability initiatives: A cross-national model. J. Bus. Ethics 2012, 105, 408-413. [CrossRef]

68. Keijzers, G. The transition to the sustainable enterprise. J. Clean. Prod. 2002, 10, 349-359. [CrossRef]

69. Hakala, H. Strategic orientations in management literature: Three approaches to understanding the interaction between market, technology, entrepreneurial and learning orientations. Int. J. Manag. Rev. 2011, 13, 199-217. [CrossRef]

70. Kwak, H.; Jaju, A.; Puzakova, M.; Rocereto, J.F. The Connubial Relationship between Market Orientation and Entrepreneurial Orientation. J. Mark. Theory Pract. 2013, 21, 141-162. [CrossRef]

71. Criado-Gomis, A.; Cervera-Taulet, A.; Iniesta-Bonillo, M.A. Sustainable Entrepreneurial Orientation: A Business Strategic Approach for Sustainable Development. Sustainability 2017, 9, 1667. [CrossRef]

72. Tranfield, D.; Denyer, D.; Smart, P. Towards a methodology for developing evidence-informed management knowledge by means of systematic review. Br. J. Manag. 2003, 14, 207-222. [CrossRef]

73. Ahmed, A.; McQuaid, R.W. Entrepreneurship, management, and sustainable development. World Rev. Entrep. Manag. Sustain. Dev. 2005, 1, 6-30. [CrossRef]

74. Dyllick, T.; Hockerts, K. Beyond the business case for corporate sustainability. Bus. Strategy Environ. 2002, 11, 130-141. [CrossRef]

75. Figge, F.; Hahn, T.; Schaltegger, S.; Wagner, M. The Sustainability Balanced Scorecard: Linking Sustainability Management to Business Strategy. Bus. Strategy Environ. 2002, 11, 269-284. [CrossRef]

76. Oguonu, C. Business Strategies for Effective Entrepreneurship: A Panacea for Sustainable Development and Livelihood in the Family. Int. J. Manag. Sustain. 2015, 4, 10-19. [CrossRef]

77. Brem, A.; Bhattacharjee, A.; Jahanshahi, A.A. Who Takes More Sustainability-Oriented Entrepreneurial Actions? The Role of Entrepreneurs' Values, Beliefs and Orientations. Sustainability 2017, 9, 1636.

78. Ashkanasy, N.M.; Windsor, C.A.; Treviño, L.K. Bad Apples in Bad Barrels Revisited: Cognitive Moral Development, Just World Beliefs, Rewards, and Ethical Decision-Making. Bus. Ethics Q. 2006, 16, 449-473. [CrossRef]

79. Egri, C.P.; Herman, S. Leadership in the North American Environmental Sector: Values, Leadership Styles, and Contexts of Environmental Leaders and their Organizations. Acad. Manag. J. 2000, 43, 571-604. [CrossRef]

80. Kirkwood, J.; Walton, S. What motivates ecopreneurs to start businesses? Int. J. Entrep. Behav. Res. 2010, 16, 204-228. [CrossRef]

81. Larson, A.L. Sustainable Innovation through an Entrepreneurship Lens. Bus. Strategy Environ. 2000, 9, 304-317. [CrossRef]

82. Vega, G.; Kidwell, R.E. Toward a Typology of New Venture Creators: Similarities and Contrasts Between Business and Social Entrepreneurs. N. Engl. J. Entrep. 2007, 10, 15-28. [CrossRef] 
83. Del Baldo, M. Family and Territory Values for a Sustainable Entrepreneurship: The Experience of Loccioni Group and Varnelli Distillery in Italy. J. Mark. Dev. Compet. 2012, 6, 120-139.

84. Tilley, F.; Young, W. Sustainability entrepreneurs-Could they be the True Wealth Generators of the Future? Greener Manag. Int. 2006, 55, 79-92. [CrossRef]

85. Thompson, J.; Alvy, G.; Lees, A. Social entrepreneurship-A new look at the people and the potential. Manag. Decis. 2000, 38, 328-338. [CrossRef]

86. Hambrick, D.C. Upper Echelons Theory: An Update. Acad. Manag. Rev. 2007, 32, 334-343. [CrossRef]

87. Hambrick, D.C.; Mason, P.A. Upper Echelons: The Organization as a Reflection of Its Top Managers. Acad. Manag. Rev. 1984, 9, 193-206.

88. Jenkins, H. Corporate social responsibility and the mining industry: Conflicts and constructs. Corp. Soc. Responsib. Environ. Manag. 2004, 11, 23-34. [CrossRef]

89. Messeghem, K. Strategic Entrepreneurship and Managerial Activities in SMEs. Int. Small Bus. J. 2003, 21, 197-212. [CrossRef]

90. Knight, G.A. Cross-cultural reliability and validity of a scale to measure firm entrepreneurial orientation. J. Bus. Ventur. 1997, 12, 213-225. [CrossRef]

91. Rennings, K. Redefining innovation: Eco-innovation research and the contribution from ecological economies. Ecol. Econ. 2000, 32, 319-332. [CrossRef]

92. Belz, F.M. Shaping the future: Sustainable innovation and entrepreneurship. Soc. Bus. 2013, 3, 311-324. [CrossRef]

93. Weerawardena, J.; Mort, G.S. Investigating social entrepreneurship: A multidimensional model. J. World Bus. 2006, 41, 21-35. [CrossRef]

94. Brush, C.G.; Chaganti, R. Businesses without glamour? An analysis of resources on performance by size and age in small service and retail firms. J. Bus. Ventur. 1999, 14, 233-257. [CrossRef]

95. Mosakowski, E.A. Resource-Based Perspective on the Dynamic Strategy-Performance Relationship: An Empirical Examination of the Focus and Differentiation Strategies in Entrepreneurial Firms. J. Manag. 1993, 19, 819-839. [CrossRef]

96. Katz, J.; Gartner, W.B. Properties of Emerging Organizations. Acad. Manag. Rev. 1988, 13, 429-441.

97. Chollet, B.; Geraudel, M.; Mothe, C. Generating Business Referrals for SMEs: The Contingent Value of CEOs Social Capital. J. Small Bus. Manag. 2013, 52, 79-101. [CrossRef]

98. Greve, A.; Salaff, J.W. Social Networks and Entrepreneurship. Entrep. Theory Pract. 2003, 28, 1-22. [CrossRef]

99. Kimmel, C.E.; Hull, R.B. Ecological Entrepreneurship Support Networks: Roles and functions for conversation organizations. Geoforum 2012, 43, 58-67. [CrossRef]

100. Tian, Z.; Wang, R.; Yang, W. Consumer responses to corporate social responsibility in China. J. Bus. Ethics 2011, 101, 197-212. [CrossRef]

101. Block, T.; Paredis, E. Urban development projects catalyst for sustainable transformations: The need for entrepreneurial political leadership. J. Clean. Prod. 2013, 50, 181-188. [CrossRef]

102. Azzone, G.; Noci, G. Seeing ecology and "green" innovations as a source of change. J. Organ. Chang. Manag. 1998, 11, 94-111. [CrossRef]

103. Kibler, E.; Fink, M.; Lang, R.; Munoz, P. Place attachment and social legitimacy: Revisiting the sustainable entrepreneurship journey. J. Bus. Ventur. Insights 2015, 3, 24-29. [CrossRef]

104. Meysen, M.; Carsrud, A.L. Nascent green-technology ventures: A study assessing the role of partnership diversity in firm success. Small Bus. Econ. 2013, 40, 739-759.

105. Vickers, I.; Lyon, F. Beyond green niches? Growth strategies of environmentally-motivated social enterprises. Int. Small Bus. J. 2012, 32, 449-470. [CrossRef]

106. Pacheco, D.F.; Dean, T.J.; Payne, D.S. Escaping the green prison: Entrepreneurship and the creation of opportunities for sustainable development. J. Bus. Ventur. 2010, 25, 464-480. [CrossRef]

107. Peters, N.J.; Hofstetter, J.S.; Hoffmann, V.H. Institutional entrepreneurship capabilities for interorganizational sustainable supply chain strategies. Int. J. Logist. Manag. 2011, 22, 52-86. [CrossRef]

108. Pinkse, J.; Groot, K. Sustainable Entrepreneurship and Corporate Political Activity: Overcoming Market Barriers in the Clean Energy Sector. Entrep. Theory Pract. 2015, 39, 633-654. [CrossRef]

109. Barrutia, J.M.; Echebarria, C. Greening regions: The effect of social entrepreneurship, co-decision and co-creation on the embrace of good sustainable development practices. J. Environ. Plan. Manag. 2012, 55, 1348-1368. [CrossRef] 
110. Cohen, B. Sustainable valley entrepreneurial ecosystems. Bus. Strategy Environ. 2005, 15, 1-14. [CrossRef]

111. Larsson, M. Environmental Entrepreneurship in Organic Agriculture in Järna, Sweden. J. Sustain. Agric. 2012, 36, 153-179. [CrossRef]

112. Carson, D.; Gilmore, A.; Rocks, S. SME Marketing Networking: A Strategic Approach. Strateg. Chang. 2004, 13, 369-382. [CrossRef]

113. Biondi, V.; Iraldo, F.; Meredith, S. Achieving sustainability through environmental innovation: The role of SMEs. Int. J. Technol. Manag. 2002, 24, 612-626. [CrossRef]

114. Longo, M.; Mura, M.; Bonoli, A. Corporate Social Responsibility and Corporate Performance: The Case of Italian SMEs. Corp. Gov. 2005, 5, 28-42. [CrossRef]

115. Hockerts, K.; Wüstenhagen, R. Green Goliaths versus Emerging Davids-Theorizing about the Role of Incumbents and Entrants in Sustainable Entrepreneurship. J. Bus. Ventur. 2010, 25, 481-492. [CrossRef]

116. Lehtonen, M. The environmental-social interface of sustainable development: Capabilities, social capital, institutions. Ecol. Econ. 2004, 49, 199-214. [CrossRef]

117. Oliver, C. Sustainable Competitive Advantage: Combining Institutional and Resource-Based Views. Strateg. Manag. J. 1997, 18, 697-713. [CrossRef]

118. Molina-Azorín, J.F.; Tarí, J.J.; Pereira-Moliner, J.; López-Gamero, M.D.; Pertusa-Ortega, E.M. The effects of quality and environmental management on competitive advantage: A mixed methods study in the hotel industry. Tour. Manag. 2015, 50, 41-54. [CrossRef]

119. Porter, M.E. Competitive Advantage: Creating and Sustaining Superior Performance; The Free Press: New York, NY, USA, 1985.

120. Rice, G. Pro-environmental Behavior in Egypt: Is there a Role for Islamic Environmental Ethics? J. Bus. Ethics 2006, 65, 373-390. [CrossRef]

121. Miles, M.P.; Munilla, L.S.; Darroch, J. Sustainable corporate entrepreneurship. Int. Entrep. Manag. J. 2009, 5 , 65-76. [CrossRef]

122. Prothero, A.; Dobscha, S.; Freung, J.; Kilbourne, W.E.; Luchs, M.G.; Qzanne, L.K.; Thogersen, J. Sustainable Consumption: Opportunities for Consumer Research and Public Policy. J. Public Policy Mark. 2011, 30, $31-38$. [CrossRef]

123. Wang, Y.B.; Ho, C.W. No Money? No Problem! The Value of Sustainability: Social Capital Drives the Relationship among Customer Identification and Citizenship Behavior in Sharing Economy. Sustainability 2017, 9, 1400. [CrossRef]

124. Brahme, U. Sharing Economy, CSR and Sustainability: Making the Connection-I. 2017. Available online: https:/ / www.linkedin.com/pulse/sharing-economy-csr-sustainability-making-connection-i-unmeshbrahme (accessed on 30 October 2017).

125. Pineiro-Chousa, J.; Vizcaíno-González, M.; López-Cabarcos, M. Reputation, Game Theory and Entrepreneurial Sustainability. Sustainability 2016, 8, 1196. [CrossRef]

126. Pineiro-Chousa, J.; Vizcaíno-González, M.; López-Cabarcos, M.Á.; Romero-Castro, N. Managing Reputational Risk through Environmental Management and Reporting: An Options Theory Approach. Sustainability 2017, 9, 376. [CrossRef]

127. Lordkipanidze, M.; Brezet, H.; Backman, M. The entrepreneurship factor in sustainable tourism development. J. Clean. Prod. 2005, 13, 787-798. [CrossRef]

128. Pastakia, A. Grassroots ecopreneurs: Change agents for a sustainable society. J. Organ. Chang. Manag. 1998, 11, 153-173. [CrossRef]

129. Bergset, L. The Rationality and Irrationality of Financing Green Start-Ups. Adm. Sci. 2015, 5, $260-285$. [CrossRef]

130. Moskwa, E.; Higgins-Desbiolles, F.; Gifford, S. Sustainability through food and conversation: The role of an entrepreneurial restaurateur in fostering engagement with sustainable development issues. J. Sustain. Tour. 2015, 23, 125-145. [CrossRef]

131. Marsden, T.; Smith, E. Ecological entrepreneurship: Sustainable development in local communities through quality food production and local branding. Geoforum 2005, 36, 440-451. [CrossRef]

132. Parrish, B.D.; Foxon, T.J. Sustainability Entrepreneurship and Equitable Transitions to a Low-Carbon Economy. Greener Manag. Int. 2006, 55, 47-52. [CrossRef]

133. Zamfir, P.B. Supporting Green Entrepreneurship in Romania: Imperative of Sustainable Development. Romanian Econ. Bus. Rev. 2014, 9, 35-44. 
134. York, J.G.; Venkataraman, S. The entrepreneur-environment nexus: Uncertainty, innovation and allocation. J. Bus. Ventur. 2010, 25, 449-463. [CrossRef]

135. Azeez Olugbola, S. Exploring entrepreneurial readiness of youth and startup success components: Entrepreneurship training as a moderator. J. Innov. Knowl. 2017, 2, 155-171. [CrossRef]

136. Cuomo, M.T.; Tortora, D.; Mazzucchelli, A.; Festa, G.; Di Gregorio, A.; Metallo, G. Impacts of Code of ethics on financial performance in the Italian listed companies of bank sector. J. Bus. Account. Financ. Perspect. 2018, in press.

137. Kraus, S.; Burtscher, J.; Niemand, T.; Roig-Tierno, N.; Syrjä, P. Configurational Paths to Social Performance in SMEs: The Interplay of Innovation, Sustainability, Resources and Achievement Motivation. Sustainability 2017, 9, 1828. [CrossRef]

138. Kraus, S.; Niemand, T.; Halberstadt, J.; Shaw, E.; Syrjä, P. Social entrepreneurship orientation: development of a measurement scale. Int. J. Entrepr. Behav. Res. 2017, 23, 977-997. [CrossRef]

(c) 2018 by the authors. Licensee MDPI, Basel, Switzerland. This article is an open access article distributed under the terms and conditions of the Creative Commons Attribution (CC BY) license (http:/ / creativecommons.org/licenses/by/4.0/). 